\title{
ゼオライト格子空間を利用したクラスター設計
}

\author{
佐 藤 満 雄 \\ 群馬大学工学部 密376 群馬県桐生市天神町 1-5-1
}

(1993 年 2 月 3 日 受理)

\section{Cluster Design Using Zeolite Lattice Space}

\author{
Mitsuo Sato \\ Molecular Design Laboratory, Applied Chemistry, \\ Faculty of Engineering, Gunma University \\ 1-5-1, Tenzin-cho, Kiryu, Gunma
}

(Received February 3, 1993)

\begin{abstract}
テクトアルミノけい酸塩の一種であるゼオライトの化学組成と 3 次元フレームワークの構造特性について 概説し，てれらゼオライト格子空間を利用したクラスターの合成法と生成クラスターの構造, 物性論的特徴 を述べた。クラスター生成の場としてのケージやチャネルは 3 次元空間中に規則配列しており，乙れら幾何 学的分布の特性を選択しクラスター濃度を制御することにより, 完全に分離したクラスターからスーパクラ スターまでの合成が可能であること，また，チャネルを利用した Se や Te の 1 次元細線の合成，導電性 ポリマー, 非線形光学細線の合成などについて, 最近の成果をまとめた。
\end{abstract}

\section{1.はじめに}

$\mathrm{SiO}_{4}$ 四面体と $\mathrm{AlO}_{4}$ 四面体を基本構成単位とするア ルミノけい酸塩の中で, 基本四面体の頂点をすべて互い に共有しあって 3 次元無限ネットワーク（フレームワー ク）を構成するむのがテクトけい酸塩であり，その中に ゼオライト群が含まれる。ゼオライト群のフレームワー クはきわめて多孔性であり, 各種陽イオン, 低有機分子, 水分子, 気体分子などを閉じ込めるケージや，通路とし てのチャネルなどが存在する。空孔中の水分子は加熱に より容易に脱水し, 沸騰現象を示すととからギリシャ語 の “boiling water”にちなんで, これらけい酸塩に対し てゼオライトという名前が与えられた。日本名では沸石 である。ゼオライトに関する研究は，1700 年代から始 まっているが，その研究のほとんよ゙は博物学的なむので あり，分子ふるいとして工業的面から検討されはじめた のは 1940 年代からである。1960 年代の触新特性発見, 1970 年代の ZSM 系ゼオライトの合成と C 1 化学への展 開を経て, 1980 年代にはゼオライトケミストリーという 分野が確立するに至った。

ゼオライトに見られる種々の特性, イオン交換, ガス
吸着, 触媒特性などはすべてゼオライト格子空間内での 反応であり，その反応には単原子，単分子，またはせい ぜい数分子程度のクラスターが関与するあのと推定され ている。とれらの挙動を制御するととにより，さまざま な機能をゼオライトに付与するととが可能であり，てれ がゼオライト化学の中心課題でああったといえよう。し かし，一方，ゼオライト格子空間を特異なクラスター生 成の場, 機能開発, 発現の場として利用する研究むロシ アの Bogomolov 教授，日本の長谷田教授らによって進 められてきた。Bogomolov らはケージ内にナノコンポ ジットサイズの半導体クラスター, チャネル内に Se や Te の 1 次元鎖などを作りだし，それらの物性が明らか に通常のバルク体と異なることを示した。最近，てれら クラスター合成と特性の研究が一段と進展し, 量子ドッ ト，量子細線などの概念がゼオライト内クラスターに適 用されるようになった。

\section{2. ゼオライト化学組成とフレームワーク 特性}

ゼオライトの化学組成は $\mathrm{SiO}_{2}$ から誘導できる。この 中の $\mathrm{Si}$ 原子の一部を $\mathrm{Al}$ 原子で置換すると電荷のアン 
バランスを生じ，それを補うために，一価のアルカリ， または二価のアルカリ土類イオンが插入される。したが って, 一般化学組成は $\mathrm{M}_{X}\left(\mathrm{Si}_{1-x} \mathrm{Al}_{X}\right) \mathrm{O}_{2} \cdot y \mathrm{H}_{2} \mathrm{O}$ として示 される。ここでMはアルカリ，またはアルカリ土類イオ ン, $\mathrm{H}_{2} \mathrm{O}$ はゼオライト水である。上に述べたのはゼオラ イト本来の化学組成であるが, 近年てれが拡張され, ゼ
オライト類似の構造をとるアルミノりん酸塩（ALPO, $\mathrm{SAPO}, \mathrm{MAPO})$, アルミノほう酸塩, ひ酸塩なども範 ちゅうに含めて検討されるととが多い。表 1 亿代表的ゼ オライトの化学組成を示す。

ゼオライトフレームワークの基本構造は前述のように $\mathrm{SiO}_{4}, \mathrm{AlO}_{4}$ 四面体であるが，乙れらが頂点を共有して

表 1 代表的ゼオライトの化学式

\begin{tabular}{|c|c|c|}
\hline ゼオライト名 & 記号 & 化 \\
\hline ゼオライトA & LTA & $\mathrm{Na}_{12}\left[\mathrm{Al}_{12} \mathrm{Si}_{12} \mathrm{O}_{48}\right] \cdot 27 \mathrm{H}_{2} \mathrm{O}$ \\
\hline ゼオライトY & FAU & $(\mathrm{Na}, \mathrm{Ca}, \mathrm{Ma})_{29}\left[\mathrm{Al}_{58} \mathrm{Si}_{134} \mathrm{O}_{384}\right] \cdot 240 \mathrm{H}_{2} \mathrm{O}$ \\
\hline モルデナイト & MOR & $\mathrm{Na}_{8}\left[\mathrm{Al}_{8} \mathrm{Si}_{40} \mathrm{O}_{96}\right] \cdot 24 \mathrm{H}_{2} \mathrm{O}$ \\
\hline ソーダライト & SOD & $\mathrm{Na}_{6}\left[\mathrm{Al}_{6} \mathrm{Si}_{6} \mathrm{O}_{24}\right] .2 \mathrm{NaCl}$ \\
\hline AIPO4-5 & AFI & $\mathrm{Al}_{12} \mathrm{P}_{12} \mathrm{O}_{48}$. R.qH ${ }_{2} \mathrm{O},\left(\mathrm{R}=\left(\mathrm{C}_{3} \mathrm{H}_{7}\right) 4 \mathrm{NOH}\right)$ \\
\hline SAPO- 47 & $\mathrm{CHA}$ & $\begin{array}{r}\mathrm{Al}_{6.0} \mathrm{Si}_{1 .}{ }_{4} \mathrm{P}_{4.6} \mathrm{O}_{24 .} \mathrm{R}_{1.4 .} \mathrm{qH} \mathrm{H}_{2} \mathrm{O} \\
\qquad\left(\mathrm{R}=\mathrm{C}_{5} \mathrm{H}_{12} \mathrm{NH}_{2}\right)\end{array}$ \\
\hline MAPO-43 & GIS & $\mathrm{Mg}_{2} \mathrm{Al}_{6} \mathrm{P}_{8} \mathrm{O}_{32}\left(\mathrm{C}_{6} \mathrm{H}_{16} \mathrm{~N}\right)_{2}$ \\
\hline
\end{tabular}

記号は，国際命名規約によるフレームワーク構造を示す

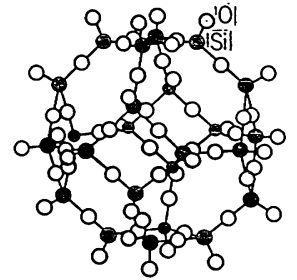

(a)

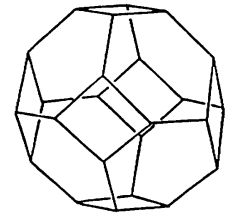

(b)

図 1 ソーダライトケージとその多面体表示

(a)：黒丸は $\mathrm{T}(\mathrm{Si}, \mathrm{Al})$ ，白丸はO原子

(b)：T原子のみの結合による多面体表示

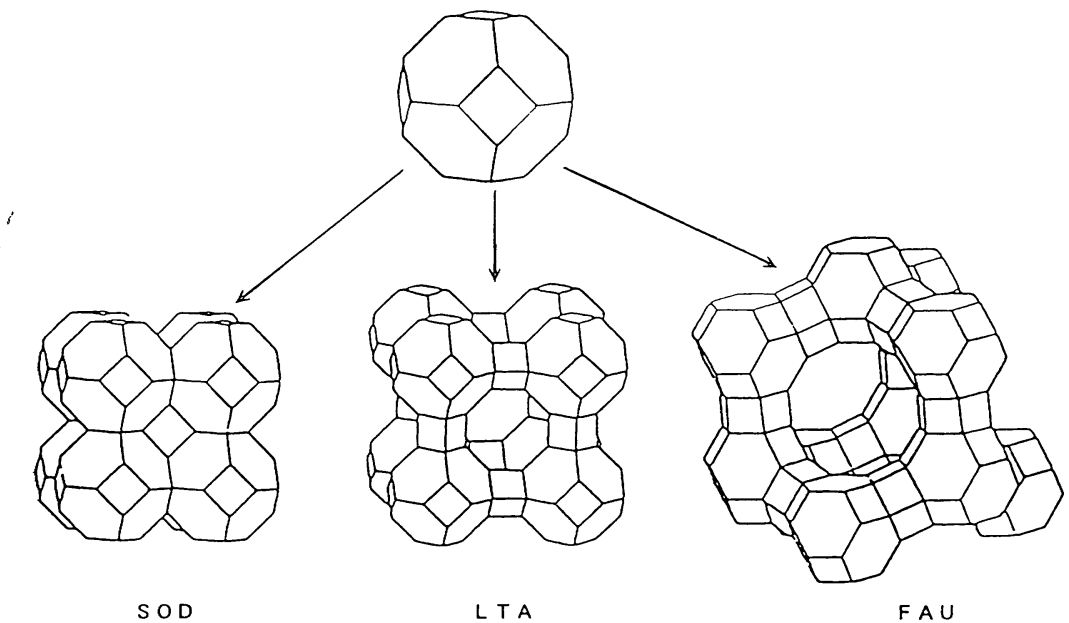

図 2 ソーダライトケージの組合せにより誘導されるゼオライト SOD : ソーダライト, LTA : ゼオライトA $\mathrm{FAU}$ : フォージャサイト, 合成ゼオライトX, Y 
作り出す 3 次元骨組み構造には多種多様なむのがあり, これらを統一的基準により特性化する試みはまだ成功し ていない。現在よく利用されている基準としては SBU (Secondary Building Unit) ${ }^{1)}$ ，または, CCL (Concentric Cluster) ${ }^{2)}$ などがある。しかし, ゼオライト多孔体 は一般に固有のケージとチャネルによって構成されてい るてとが多く(そうでないのああるが)，乙れらの種類と 組合せでフレームワークの特徵を把握するのが簡便で, しかむわかりやすい。たとえば, 図 1 亿示すように, 比 較的広くゼオライト構造にみられるソーダライトケージ は 4 員環 6 個と 6 員環 8 個より構成された 18 面体で あるが，図 2 亿示すように，乙れが 4 員環を共有して結 合したあのがゼオライト名のソーダライト(SOD), 間に 2 重四員環を介して結合したものがゼオライトA（リン デタイプA：LTA），2重六員環を介して結合したもの がフォージャサイト (FAU) である。しかし一方，てれ らのケージの組合せはさらに新しいケージやチャネルを 生成する。たとえばゼオライトA（LTA）に执いてはン ーダライトケージの組合せにより, 新たに, 4 員環 12 個 之 6 員環 8 個, 8 員環 6 個から構成された 26 面体の $\alpha$ ケージや，X, Y, Z 方向に相互に直交する直径 $4.1 \AA$ の 8 員環チャネル，同様に FAU では 4 員環 18 個，6 員環 4 個, 12 員環 4 個から構成されるスーパケージと, 〈111〉方向にのびた直径が $7.4 \AA$ の 12 員環チャネルが 新たに生成されている。チャネルの形態とそれらの組合 せにあ多梯性があり，カンクリナイト(CAN)のように, そのサイズが均一で相互に一定間隔で平行に走るあのか ら，モルデナイト(MOR) のように主チャネルに副チャ ネルが直交交差しているあのなどさまざまである。図 3

(a)

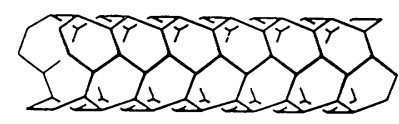

(b)

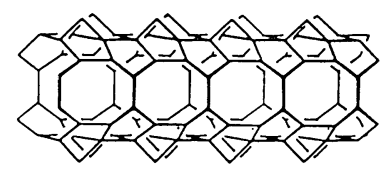

(c)

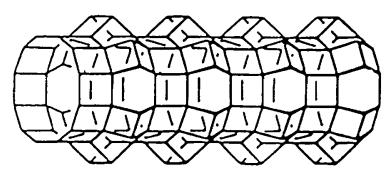

図 3 ゼオライト格子内のチャネル (a)：カンクリナイトチャネル，(b)：モル デナイトチャネル，（c）：オメガチャネル
にそれらのいくつかを示す。特に注意すべきことはこれ らケージやチャネルなどは 3 次元空間中に一定間隔で分 布するので，乙のようなケージやチャネルの特性を生か して, 取り込んだ原子や分子間相互作用を制御し，量子 効果を生み出す場を確保するととが可能となることであ る。

\section{3. ゼオライト格子空間を利用したクラス ターの合成と特徵}

\section{1 量子ドット}

量子ドットとして物性論的に興味のあたれているあの は無機クラスターであり, 現在までにつぎのようなあの が合成され，特性が調べられている。

アルカリ金属

$$
\mathrm{Na}_{4}{ }^{3+}, \mathrm{K}_{4}{ }^{3+}
$$

硫化物

$\mathrm{Zn}_{4} \mathrm{~S}_{4}, \mathrm{Zn}_{4} \mathrm{~S}, \mathrm{Cd}_{4} \mathrm{X}_{4}[\mathrm{X}=0, \mathrm{~S}, \mathrm{Se}, \mathrm{Te}], \mathrm{Cd}_{4} \mathrm{Se}$,

$\mathrm{PbS}, \mathrm{PbS}_{2}{ }^{2-}, \mathrm{Na} \mathrm{T}_{4} \mathrm{Te}, \mathrm{Na}_{10} \mathrm{Te}_{12}$,

りん化物

$\mathrm{Ga}_{28} \mathrm{P}_{13}, \mathrm{Zn}_{3} \mathrm{GaP}$

タングステン酸化物

$\mathrm{WO}_{3},\left(\mathrm{WO}_{3}\right)_{4}$

銀ハロゲン化物

$\mathrm{AgX}[\mathrm{X}=\mathrm{Cl}, \mathrm{Br}, \mathrm{I}], \mathrm{Ag}_{n} \mathrm{X}, \mathrm{Na}_{n} \mathrm{Ag}_{4-n}$

これらはフレームワーク内での ( a ) 気相輸送法, (b) イオン交換法, (c) 両法の組合せなどにより創りだされ ている。たとえば ZnS のような 2 元化合物は，あらか じめイオン交換により Zn イオンをケージ内に入れてお き, その後で $\mathrm{H}_{2} \mathrm{~S}$ 気相を送り込み合成する。ケージと してはソーダライトケージやスーパケージを利用したむ のが压倒的に多い。ゼオライトとしては，ゼオライト

$\mathrm{A}, \mathrm{X}, \mathrm{Y}$ ソーダライトなどが多い。

具体例として Herron ら ${ }^{3)}$ にり合成された CdS ク ラスターの構造と特性を以下に示す。彼らはあらかじめ $\mathrm{Cd}$ イオン交換したフォージャサイト (FAU) 内に $\mathrm{H}_{2} \mathrm{~S}$ ガスを通じて, CdS クラスターを合成し，その構造を粉 末シンクロトロンX線回折法, および抎張 $\mathrm{X}$ 線吸収端微 細構造 (EXAFS) 法により解析した結果, 図 4 亿示すよ. うな $\mathrm{Cd}_{4} \mathrm{~S}_{4}$ クラスター (Cd-S 原子距離 $\left.2.47 \AA\right)$ の存在 を確認した。バルクとしての CdS は安定に存在しうる が，クラスター分子としての CdS は不安定であり，そ の存在はまったく確認されていなかった。てのクラスタ 一はスーパケージ内には存在せず, ソーダライトケージ 内のみに安定に存在する理由として, 図に示すように, $\mathrm{Cd}$ 原子がンーダライト構造中の 2 重 6 員環の 0 原子 3 個と強く結びついており (2.48 ̊), その配位性が満足 

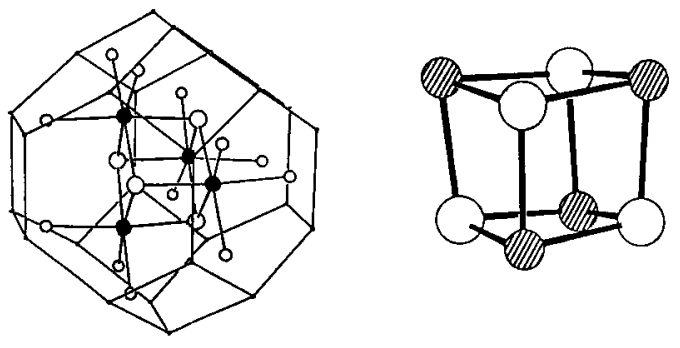

(a)

(b)

図 4 ゼオライト $\mathrm{Y}$ 中の $\mathrm{Cd}_{4} \mathrm{~S}_{4}$ クラスター ${ }^{3)}$ (a)：ソーダライトケージ内における $\mathrm{Cd}_{4} \mathrm{~S}_{4}$ の配向 構造。黒丸は $\mathrm{Cd}$, 大白丸は $\mathrm{S}$ ，小白丸はフレーム ワークを構成するO原子, (b) : $\mathrm{Cd}_{4} \mathrm{~S}_{4}$ クラスター

されているためと説明されている。これらクラスターに ついての CdS 光吸収スペクトルを図 5 に示す。図中の （a）はバルクとしての CdS，（b ) は CdS 含量 7.4\% (重 量）の試料，(c)は CdS 含量が $1.1 \%$ の靠料からのス ペクトルである。（c）にみられるように CdS 含有量が $4 \%$ 以下の場合, てれら CdS クラスターは班立状態 にあり，短波長側にシフトした，いわゆるブルーシフト が明らかである。含有量がそれ以上では，(b)にみられ るように $350 \mathrm{~nm}$ にエキシトン状のスペクトルを生じ, スーパクラスターの形成が示焧された。しかし，隣合う ケージ間での Cd-Cd の距離は約 $6 \AA$ であり, 両クラス ターの波動関数の重なりは期待できない。長範团相互作 用機構として，(1)ゼオライトフレームワークを介し て，(2) 2 重6 員環内に捕獲された化学種を介して，の

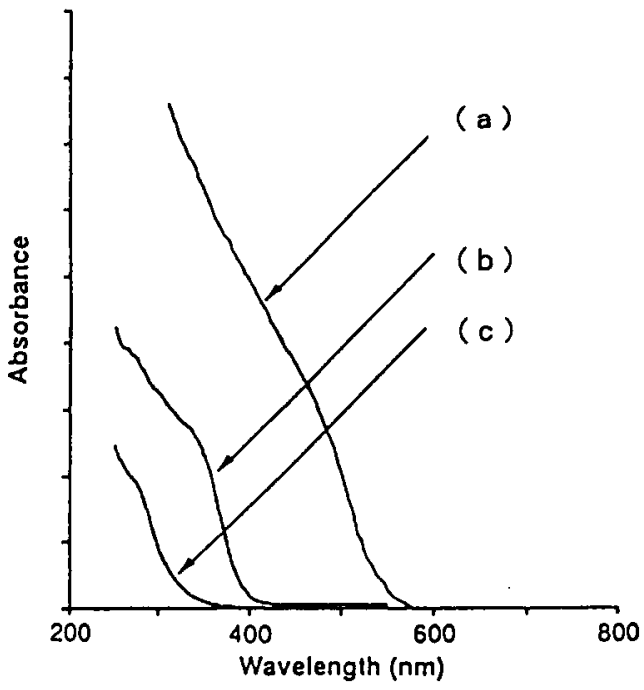

图 5 生成 CdS クラスターの光学吸収スペクトル32 (a) : CdSバルク, (b) : CdS 含有量 7.4 重量\%, (c): CdS 含有量 1.1 重量\% (a)

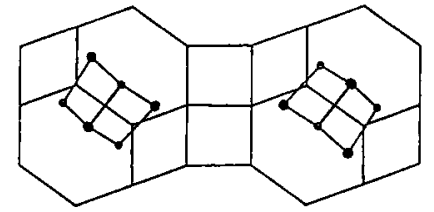

(b)

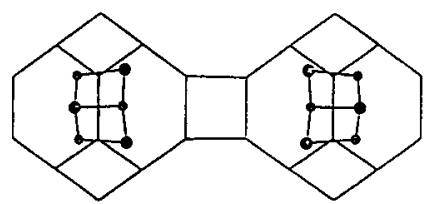

図 6 相隣接するソーダライトケージ中における 2 組の $\mathrm{Cd}_{4} \mathrm{~S}_{4}$ の配向関係3)。黒丸は $\mathrm{Cd}$, 白丸は $\mathrm{S}$ 原子を示す

(a)：2重6員環を介したゼオライト(FAU)

(b) : 2 重 4 員環を介したゼオライト (LTL)

二つが考えられたが，前者のフレームワークを介した， すなわち Cd-O-Al-O-Si-O-Cd ブリッジによる相互作用 の存在の可能性が示唆されている。一方ての 2 重 6 員環 の代わりに，2重 4 員環でソーダライトケージを結びつ けたあのがゼオライトAであるが，図6亿示すように， 乙の場合, 隣合う $\mathrm{CdS}$ クラスターの Cd-Cd 原子間距離 は $9 \AA$ となり，吸収バンドがよりブルーシフトすること が予想される。実測データ $320 \mathrm{~nm}$ はこの予想の罗当性 を示している。逆に，ソーダライトケージを直接, 面共 有したソーダライトそのものでは, クラスターそのもの の間の距離が短縮し，スペクトルはレッドシフトする。

Ozin ら4) 忧オライトソーダライトに Ag の元素単 体，八ロゲン化物、硫酸塩，炭酸塩，葆酸塩などを溶哣 塩または銀塩水溶液中でイオン交換法により閉じこ め, 生成物の構造, 光学吸収スペクトルなどを調べ, 添 加 $\mathrm{Ag}$ の濃度により $\mathrm{CdS}$ 上同様, フレームワークを介 した長範囲相互作用のスーパクラスターの生成を確認し ている。また,ケージ内に $\mathrm{Na}_{n} \mathrm{Ag}_{4-n}(n=0 \sim 4)$ クラス タ一の生成を電顕，X線法により確認した。

最近, Nozue ら ${ }^{5,6)}$ はゼオライトL(LTL) 内のケージ 内で合成したKクラスターが $4 \mathrm{~K}$ 以下の低温条件下で強 磁性体となることを示した。

てのように，ゼオライトケージの空間分布特性を選択 し、クラスター浱度を制御するととにより,クラスター そのものの特性のみならず,クラスター間の相互作用を 自由に制御することも可能である。

\section{2 子細線}

前述のように，ゼオライトフレームワーク内に Se や Te を閉じこめ1次元銷をつくる試みは，Bogomolov ら 781 にってはじめられた。彼らはモルデナイト(チャ ネル径 $6.5 \sim 7.0 \AA$ ) の1次元チャネル内に溶融塩中での 
表 $2 \mathrm{Se}$ バンドギャップの比較9)

\begin{tabular}{lc}
\hline \multicolumn{1}{c}{$\mathrm{Se}$ 試料 } & バンドギャップ $(\mathrm{eV})$ \\
\hline $\mathrm{t}-\mathrm{Se}($ trigonal) & 1.98 \\
$\alpha$-Se(monoclinic) & 2.53 \\
So-MOR-9 & 2.25 \\
Se-AlPO5-15 & 2.4 \\
Se-A-6 & 2.85 \\
Se-X-26 & 2.3 \\
Se-Y-34 & 2.2 \\
\hline
\end{tabular}

試料の記号 Se-MS-WT における MS はゼオライト種, WT は Se の含有重量 \% を示す。 MOR: モルデナイト,ALPO5: アルポ 5, A : ゼオライトA, $\mathrm{X}$ : ゼオライト $\mathrm{X}, \mathrm{Y}$ : ゼオライト $\mathrm{Y}$

圧縮法, または, 気相輸送法により Se や Te の 1 次元 鎖をつくるのに成功した。その後 Parise ら"9 は，ゼオラ イト $\mathrm{A}($ 径 $4.1 \AA$ )，ゼオライトX，およびY(径 $7.4 \AA$ )， AlPO-5 (径 7.3 $\AA$ )，モルデナイト(径 6.5〜7.0 ) チ 中ネル内に Se ガスを導入し, 拡張 X 線吸収微細構造, 核磁気共鳴，光学吸収スペクトル法により，AlPO-5, モルデナイト,ゼオライト X, Y 中には高周期性の Se ら せん鎖，ゼオライトAには Se の 8 員環が形成されてい るととを確認報告している。表 2 亿てれら Se のバンド ギャップを示す。 $0.2 \sim 0.3 \mathrm{eV}$ のブルーシフトは生成ク ラスターが十分孤立した状態での量子効果によるあのと 推定されている。しかし，乙れらの構造については十分 な X 線構造解析がなされていない。最近, Paborchii ${ }^{10}$ は微細単結晶カンクリナイトチャネル内（径 $5.9 \AA$ ）に $\mathrm{Se}$ 鎖を閉じ込め, 温度変化化伴うラマンスペクトル変 化より, $\mathrm{Se}$ 鎖の構造変化を追跡し，カンクリナイトホ ストと Se 鎖間の相互作用が著しく大であることを指摘 している。Sato' ${ }^{11)}$ はこの試料について, 単結晶低温X線 回折法により温度変化に関連した構造変化の詳細を解析 し，室温でほとんご直線状に配列している Se 鎖は，温 度低下と共に，らせん鎖を形成する傾向があることを見 出している。

\section{3 導電性ポリマー, 非線形光学材料の合成}

ゼオライトチャネルを利用してポリマー細線, 特に導
電性ポリマー細線を合成する試みが意欲的になされてい る。Bein ら ${ }^{12 \sim 14)}$ はあらかじめ $\mathrm{Fe}(\mathrm{III})$ または $\mathrm{Cu}(\mathrm{II})$ イオン処理を行ったゼオライトY，モルデナイトなどに それぞれの単量体をガス吸着させ，チャネル内酸化重合 反応により, ポリピロール，ポリアニリン，ポリチオフ エン，ポリアクリロニトリルなどの導電性ポリマーを比 較的容易に合成するてとができる。Sato' ${ }^{15}$ (は電子スピン 共鳴スペクトルと吸収スペクトル法によりてれらにいず れあ固有のラジカルとポーラロンの存在を確認した。ま た，一部のゼオライト中ではポーラロンはバイポーラロ ンとして安定に存在するととも確認した。これら 1 次元 ポリマーモデルを図 7 に示す。（a）はポリピロール（-C 4 $\left.\mathrm{H}_{3} \mathrm{~N}-\right)_{n}, \quad(\mathrm{~b})$ はポリフラン $\left(-\mathrm{C}_{4} \mathrm{H}_{2} \mathrm{O}-\right)_{n}$, ( c c)はポリア ニリン $\left(-\mathrm{C}_{6} \mathrm{H}_{5} \mathrm{~N}-\right)_{n}$ のポーラロンモデルを示す。ポー ラロンとは格子歪を伴ったラジカルイオンであり図中の 十がイオンを・が不対電子を示す。しかし，現在のとと ろ，てれらゼオライト内で生成した導電体には期待され るほどの導電特性は確認されていない。Cox ら ${ }^{16,17)}$ はゼ オライトY,オメガ, モルデナイト, アルポ 5 にパラニ トロアニリン芳香族化合物をガス吸着させ, 結晶構造的 に対称中心性をむたないアルポ 5 のみにホストーゲスト 間相互作用に起因する第 2 高調波発生 (SHG) を確認で きたてとを報告している。2-メチルパラニトロアニリン についてはどのホストゼオライトについてもてのような

(a)

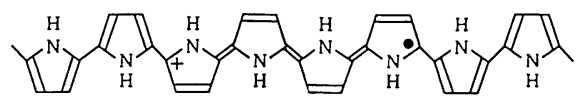

(b)

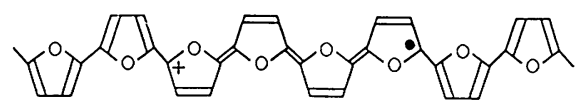

(c)

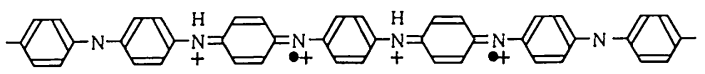

図 7 ポーラロン状態にある導電性ポリマーモデル

(a) : ポリピロール, (b) : ポリフラン, (c)：ポリアニリン 
高調波は確認されなかった。乙れは分子外形による制限 のためゼオライト格子内に入れなかったためと説明され ている。このほか，モルデナイト，オメガ，ゼオライト L, ゼオライトY, ベータ, ZSM 5, サポ 5 中でのメチ ルアセチレンのオリゴマー合成も報告されている。

\section{4. おわりに}

以上述べてきたように，ゼオライト格子空間はクラス ター生成の場としてのみならず，クラスター物性を探る 場としてもユニークな空間である。クラスター合成には 高額で大規模な装置を必要とせず，ありふれた器具で十 分である。ホストとしてのゼオライトは低温水熱条件下 で比較的簡単に合成される。ALPO, SAPO 系も含めて 現在まで約 90 種ほどの種類が知られているが，新しい フレームワークの開発む順調にすすめられており，最近 はチャネルサイズ径が $40 \AA ̊$ のむのも合成されるように なった。しかし, 一方, 構造决定や物性測定に十分なサ イズの単結晶試料の合成が困難なため種々の素子として の利用が進まない難点むあるが, 粉末試料のままでの特 性を利用した未開拓の興味ある問題が山積しており，そ の意味でも多くの方々が本拙文により関心をお寄せいた だければ幸いである。

\section{文献}

1) W. M. Meier: "Molecular Sieves" (Society of Chemical Industry, London, 1968) p. 10.

2) M. Sato: J. Phys. Chem. 91, 4675 (1987).

3) N. Herron, Y. Wang, M. M. Eddy, G. D. Stucky,
D. E. Cox, K. Moller and T. Bein : J. Am. Chem. Soc. 111, 530 (1989).

4) G. A. Ozin, A. Kuperman and A. Stein : Angew. Chem. Int. Ed. Engl. 28, 359 (1989).

5) Y. Nozue, T. Kodaira and T. Goto: Phys. Rev. Lett. 68, 3789 (1992).

6) Y. Nozue, T. Kodaira and S. Ohwashi : Proc. 2 nd Russian-Japanese Meeting (1992) 17.

7) V. N. Bogomolov, E. L. Lutsenko, V. P. Petranovskii : Pis'ma Zh. Eksp. Teor. Fiz. 23, 528 (1976).

8) V. N. Bogomolov, S. V. Kholokevich, S. G. Romanov and L. S. Agroskin: Solid State Commun. 47, 181 (1983).

9) J. B. Parise, J. E. MacDougall, N. Herrron, R. Farlee, A. W. Slight, Y. Wang, T. Bein, K. Moller and L. M. Moroney: Inog. Chem. 27, 221 (1988).

10) V. V. Poborchii : Solid State Phys. 34, 1722 (1992).

11) M. Sato and V. V. Poborchii : in prepararion.

12) P. Enzel and T. Bein : J. Phys. Chem. 93, 6270 (1989).

13) P. Enzel and T. Bein : J. Chem. Soc. Commun. 1326 (1989).

14) P. Enzel and T. Bein: Chem. Mater. 4, 819 (1992).

15) M. Sato : Proc. 2 nd Russian-Japanese Meeting, (1992) 10.

16) S.D. Cox, T.E. Gier, G.D. Stucky and J.B. Bierlein : J. Am. Chem. Soc. 110, 2986 (1988).

17) S. D. Cox and G. D. Stucky : J. Phys. Chem. 95. 710 (1991). 